Supporting Information 


\section{Altered Cell Cycle Arrest by Multifunctional Drug-Loaded \\ Enzymatically-triggered Nanoparticles}

Can Huang, Ying Sun, Ming Shen, Xiangyu Zhang, Pei Gao, Yourong Duan*

State Key Laboratory of Oncogenes and Related Genes, Shanghai Cancer Institute, Renji Hospital, School of Medicine, Shanghai Jiao Tong University, Shanghai, China

*Correspondence: Yourong Duan.

Tel/Fax: +86-21-64437139. E-mail: yrduan@shsci.org.

\section{EXPERIMENTAL SECTION}

1.1. Synthesis of $c R G D-P E G_{1 K}-P L G A .1 \mathrm{~g}$ of PLGA (Mw=10000, $\left.1 \times 10^{-4} \mathrm{~mol}\right)$ was first dissolved in $5 \mathrm{~mL}$ of dichloromethane. Then $76.68 \mathrm{mg}\left(4 \times 10^{-4} \mathrm{~mol}\right)$ of EDC and $23.02 \mathrm{mg}$ $\left(2 \times 10^{-4} \mathrm{~mol}\right)$ of NHS were added to the above solution. After the solution was stirred for 2 $\mathrm{h}$ at room temperature, $100 \mathrm{mg}$ of $\mathrm{COOH}-\mathrm{PEG}_{1 \mathrm{~K}}-\mathrm{NH}_{2}\left(1 \times 10^{-4} \mathrm{~mol}\right)$ was added and the reaction solution was stirred continuously for $4 \mathrm{~h}$. The product was poured into $50 \mathrm{~mL}$ cold diethyl ether. The precipitate (COOH-PEG $\left.{ }_{1 \mathrm{~K}}-\mathrm{PLGA}\right)$ was collected and then dried in vacuum oven.

$0.55 \mathrm{~g}$ of $\mathrm{COOH}-\mathrm{PEG}_{1 \mathrm{~K}}-\mathrm{PLGA}\left(0.5 \times 10^{-4} \mathrm{~mol}\right)$ was first dissolved in $3 \mathrm{~mL}$ of dichloromethane. Then $38.34 \mathrm{mg}\left(2 \times 10^{-4} \mathrm{~mol}\right)$ of EDC and $11.51 \mathrm{mg}\left(1 \times 10^{-4} \mathrm{~mol}\right)$ of NHS were added to the above solution. After the solution was stirred for $2 \mathrm{~h}$ at room temperature, $100 \mathrm{mg}$ of $\mathrm{CRGD}\left(1 \times 10^{-4} \mathrm{~mol}\right)$ was added and the reaction solution was stirred continuously for $4 \mathrm{~h}$. The resultant product was evaporated to remove dichloromethane. Some distilled water was added to the product. The solution was centrifuged (16 $000 \mathrm{rpm} \times 30 \mathrm{~min}$ ) and lyophilized to obtain a white powder.

1.2. Synthesis of PEG ${ }_{5 K}-$ peptide-PLGA. Peptide ( $24.6 \mathrm{mg}, 0.021 \mathrm{mmol}$ ) and $P E G_{5 K^{-}}$ $\mathrm{NH}_{2}(102 \mathrm{mg}, 0.024 \mathrm{mmol})$ were dissolved in $1 \mathrm{~mL}$ DMSO. EDC (18.40 mg, $\left.0.096 \mathrm{mmol}\right)$ 
was added to the solution. After the solution was stirred for $15 \mathrm{~min}$, NHS (5.524 mg, $0.048 \mathrm{mmol}$ ) was added and the reaction solution was stirred continuously for $4 \mathrm{~h}$ at room temperature. The reaction solution was dialyzed in distilled water and lyophilized to

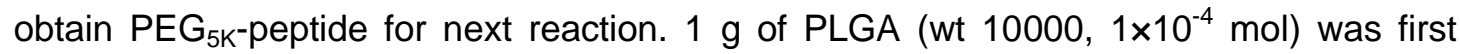
dissolved in $5 \mathrm{~mL}$ DMSO. Then EDC $\left(76.68 \mathrm{mg}, 4 \times 10^{-4} \mathrm{~mol}\right)$ and NHS $\left(23.02 \mathrm{mg}, 2 \times 10^{-4}\right.$ mol) were added to the above solution. After the solution was stirred for $2 \mathrm{~h}$ at room temperature, $P E G_{5 k}$-peptide was added and the mixture was stirred continuously for another $4 \mathrm{~h}$. The reaction solution was dialyzed in distilled water and lyophilized to obtain a white powder.

1.3. Synthesis of cis,cis, trans- $\left[\mathrm{PtCl}_{2}\left(\mathrm{NH}_{3}\right)_{2}(\mathrm{OH})\left(\mathrm{O}_{2} \mathrm{CCH}_{2} \mathrm{CH}_{2} \mathrm{CO}_{2} \mathrm{H}\right)\right]$. cis, cis, trans$\left[\mathrm{PtCl}_{2}\left(\mathrm{NH}_{3}\right)_{2}(\mathrm{OH})\left(\mathrm{O}_{2} \mathrm{CCH}_{2} \mathrm{CH}_{2} \mathrm{CO}_{2} \mathrm{H}\right)\right][\mathrm{Pt}(\mathrm{IV})]$ was synthesized according to reference with some modification. ${ }^{1}$ Two main steps were carried out during the synthesis of $\mathrm{Pt}(\mathrm{IV})$. First, $\mathrm{Pt}(\mathrm{II})(50 \mathrm{mg}$ ) was dispersed in $2 \mathrm{~mL}$ water. Then, $2 \mathrm{~mL}$ hydrogen peroxide was added to the solution. The mixture was stirred at $50^{\circ} \mathrm{C}$ for $1 \mathrm{~h}$ in a dark chamber. The product was allowed to re-precipitate at $4^{\circ} \mathrm{C}$ for $3 \mathrm{~h}$. Then, it was washed three times with ice water, ethanol and diethyl ether in order, dried in vacuum oven and a yellow power known as disuccinato-cisplatin $\left[\left(\mathrm{Pt}\left(\mathrm{NH}_{3}\right)_{2} \mathrm{Cl}_{2}(\mathrm{OH})_{2}\right]\left[\mathrm{Pt}(\mathrm{OH})_{2}\right]\right.$ was obtained for next reaction. $50 \mathrm{mg}$ of $\mathrm{Pt}(\mathrm{OH})_{2}$ was dissolved in $3 \mathrm{~mL}$ DMSO, and $15 \mathrm{mg}$ of succinic anhydride was added to the above solution. Then the solution was stirred for $24 \mathrm{~h}$ at room temperature. The product was lyophilized. $10 \mathrm{~mL}$ of acetone was added to the product and the precipitate was collected. Then, it was washed three times with acetone and cold diethylether in order, dried in vacuum oven and Pt(IV), a light yellow power, was obtained. Stored it at $4^{\circ} \mathrm{C}$ for use.

1.4. Synthesis of $\mathrm{Au}-\mathrm{Pt}(\mathrm{IV})$ nanoparticles. There were three main steps for the synthesis. First, Au nanoparticles were synthesized according to the reference. ${ }^{2} 20 \mathrm{~mL}$ of $\mathrm{HAuCl}_{4}(1 \mathrm{mM})$ was heated to $100^{\circ} \mathrm{C}$ with continuous stirring. Upon boiling, $2 \mathrm{~mL}$ of 
sodium citrate $(1 \%, \mathrm{~m} / \mathrm{v})$ was added to the solution. The mixture was stirred for another 30 min during which the color of the solution changed to deep red implying $\mathrm{Au}$ nanoparticles was formed. Allowing the solution to cool naturally to room temperature, stored it at $4^{\circ} \mathrm{C}$ for use.

Then $1 \mathrm{~mL}$ of 2 -aminoethanethiol $(0.04 \mathrm{~mol} / \mathrm{L})$ aqueous solution was prepared. 17.36 $\mathrm{mg}$ of $\mathrm{Pt}(\mathrm{IV}), 12 \mathrm{mg}$ of EDC and $10 \mathrm{mg}$ of $\mathrm{NHS}$ were dissolved in the solution. The mixture was stirred for $4 \mathrm{~h}$ at the room temperature. The resultant product cis,cis,trans$\left[\mathrm{PtCl}_{2}\left(\mathrm{NH}_{3}\right)_{2}(\mathrm{OH})\left(\mathrm{O}_{2} \mathrm{CCH}_{2} \mathrm{CH}_{2} \mathrm{CONHCH}_{2} \mathrm{CH}_{2} \mathrm{SH}\right][\mathrm{Pt}(\mathrm{IV})-\mathrm{SH}]\right.$ was lyophilized. $60 \mu \mathrm{L}$ of distilled water was added to the power. The concentration of Pt was measured by ICPMS.

At last, the mixture of $\mathrm{Pt}(\mathrm{IV})-\mathrm{SH}$ and the Au nanoparticles was incubated for $30 \mathrm{~min}$ at room temperature. The resulting $\mathrm{Au}-\mathrm{Pt}(\mathrm{IV})$ were washed three times with water with Amicon Untra-4 centrifugal Filter units (3000 D) and resuspended in water for storage. The size and morphology were confirmed by transmission electron microscope (TEM, JEM-1400).

1.5. Prepare of Au-Pt(IV)@PEG ${ }_{1 \kappa}-P L G A / P E G_{5 k}-$ peptide-PLGA. $8 \mathrm{mg}$ of mixture of NPs-cRGD was dissolved in $400 \mu \mathrm{L}$ dichloromethane. $40 \mathrm{uL}$ of Au-Pt (Pt, $10 \mathrm{mg} / \mathrm{mL})$ was added to the solution. The mixture was sonicated ( $350 \mathrm{w}, 1 \mathrm{~min}$ ) using ultrasonic cell disruptor (JY92-II, China). The emulsion was added to the $4.4 \mathrm{~mL}$ of PluronicTM F68 (0.5\%) aqueous solution and sonicated again (300 w, $1 \mathrm{~min})$. The resultant emulsion was stirred for $1 \mathrm{~h}$ at room temperature to remove the dichloromethane. A light blue solution was obtained. The resulting NPs-cRGD were washed three times with water with Amicon Untra-4 centrifugal Filter units $(100 \mathrm{KD})$ and resuspended in water for storage. The nanoparticles were characterized by TEM and DSL (Zetasizer Nano ZS). Pt content was examined by ICP-MS (ICP-710ES). Encapsulation efficiency and drug loading were calculated. 
1.6. Prepare of PTX@NPs-cRGD. $8 \mathrm{mg}$ of NPs-cRGD was dissolved in $400 \mu \mathrm{L}$ dichloromethane. $200 \mu \mathrm{g}$ of PTX dichloromethane solution $(5 \mathrm{mg} / \mathrm{mL})$ was added to the solution. After $10 \mathrm{~min}$, the mixture was added to $4.4 \mathrm{~mL}$ of Pluronic ${ }^{\mathrm{TM}} \mathrm{F} 68(0.5 \%)$ aqueous solution and sonicated $(350 \mathrm{w}, 1.5 \mathrm{~min})$ as the method above. The resultant emulsion was stirred for $1 \mathrm{~h}$ at room temperature to remove the dichloromethane. The light blue solution was centrifuged (3000 rpm $\times 2$ min) and PTX@NPs-cRGD were acquired. The nanoparticles were characterized by TEM and DSL. PTX content was examined by HPLC (Agilent 1200). Encapsulation efficiency and drug loading were calculated.

1.7.. Prepare of ADR@NPs-cRGD. $10 \mathrm{mg}$ of NPs-cRGD was dissolved in $400 \mu \mathrm{L}$ dichloromethane. $40 \mu \mathrm{L}$ of ADR $N$-Ethylacetamide solution $(10 \mathrm{mg} / \mathrm{mL})$ was added to the solution. The resultant emulsion was stirred for $1 \mathrm{~h}$ at room temperature to remove the dichloromethane. The resulting NPs-cRGD were washed three times with water with Amicon Untra-4 centrifugal Filter units $(100 \mathrm{KD})$ and resuspended in water for storage. ADR content was examined by ultraviolet spectroscopy at $480 \mathrm{~nm}$ (UV, cary 500). Encapsulation efficiency and drug loading were calculated.

\section{RESULTS AND DISCUSSION}

2.1. Generation and Characterization of Nanoparticles. PLGA-PEG ${ }_{1 K}-C R G D$ and PEG $_{5 K}$-peptide-PLGA were synthesized by a series of condensation polymerizations between the amino and carboxylic groups (Scheme S1a, S1b. In the 1H NMR spectrum (Supplementary Fig. S1), the peak corresponding to methylenes from the glycolide units of PLGA was clearly observed at $\delta=4.9 \mathrm{PPm}$, along with methyls at $\delta=1.5 \mathrm{PPm}$ and methylidynes at $\delta=5.2 \mathrm{PPm}$, both from the lactide units of PLGA. In addition to the special peaks from PLGA, the peak corresponding to methylene from PEG at $\delta=3.5$ PPm 
appeared for the PLGA-PEG 1 and $P E G_{5 K}$-peptide-PLGA, indicating that $P E G_{1 K}$ and $P E G_{5 K}$-peptide conjugates were introduced at the C-terminus of PLGA.

The structure of $\mathrm{Pt}(\mathrm{IV})$ was confirmed by ESI-MS $[(\mathrm{M}-\mathrm{H})$ Calcd. $=434.98$, Found=434.0] an d 1H NMR [(DMSO-d6) $\delta=6.52 \mathrm{PPm}(\mathrm{br}, 6 \mathrm{H}), \delta=2.97-1.97(\mathrm{~m}, 4 \mathrm{H})]$. TEM (Supplementary Fig. S2a) clearly showed that the average sizes of $\mathrm{Au}$ nanoparticles were approximately $5 \mathrm{~nm}$ and that $\mathrm{Au}-\mathrm{Pt}(\mathrm{IV})$ increased in size to approximately $10 \mathrm{~nm}$ (Supplementary Fig. S2a), which indicated that $\mathrm{Pt}(\mathrm{IV})$ was deposited on the surface of the Au nanoparticles with a certain thickness. For the spherical Au nanoparticles, the plasmon resonance was reflected in the UV/Vis spectrum by a broad absorption band in the visible region, centered at approximately $523 \mathrm{~nm}$ (Supplementary Fig. S2b). For the Au-Pt(IV) nanoparticles, the typical peak disappeared, which indicated that $\mathrm{Pt}(\mathrm{IV})$ was deposited on the surface of the Au nanoparticles. These data demonstrated that $\mathrm{Pt}(\mathrm{IV})$ was effectively connected to the surface of the $\mathrm{Au}$ nanoparticles by disulfide bond.

\section{Supplementary Table}

Table S1. Optimal Mass Ratio of PLGA-PEG $1 \mathrm{~K}-\mathrm{CRGD} / \mathrm{PEG} \mathrm{GK}_{5}$-peptide-PLGA Based on Encapsulation Efficiency, Drug loading and Size.

\begin{tabular}{cccc}
\hline $\begin{array}{c}\text { PLGA-PEG } \\
{ }_{1 k}-c R G D /\end{array}$ & ${ }^{a} E E(\%)$ & ${ }^{b} \mathrm{DL}(\%)$ & Size $(\mathrm{nm})$ \\
PEG $_{5 \mathrm{~K}}$-peptide-PLGA: mass ratio & & & \\
\hline $1: 1$ & $22.6 \pm 4.6$ & $1.13 \pm 0.23$ & $175.13 \pm 3.23$ \\
$1: 4$ & $34.3 \pm 2.57$ & $1.72 \pm 0.13$ & $179.4 \pm 2.23$ \\
$1: 8$ & $42.3 \pm 3.20$ & $2.21 \pm 0.03$ & $182.9 \pm 2.12$
\end{tabular}

$\overline{{ }^{a} \text { Encapsulation efficiency. }{ }^{b} \text { Drug loading. Data were represented as mean } \pm S D}(n=3)$. 
Supplementary Figures

a

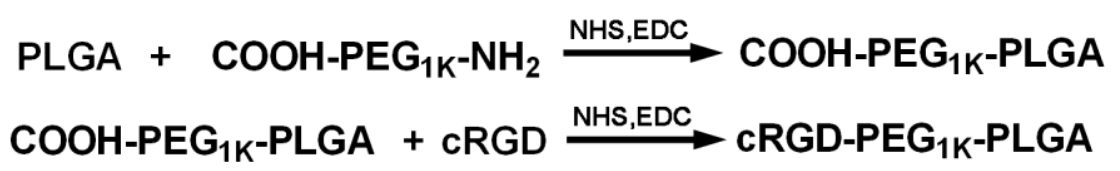

b

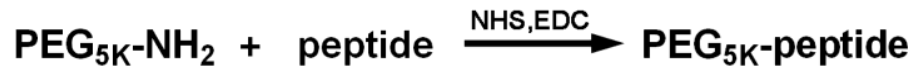

$\mathrm{PEG}_{5 \mathrm{~K}}$-peptide + PLGA $\stackrel{\mathrm{NHS}, \mathrm{EDC}}{\longrightarrow} \mathrm{PEG}_{5 \mathrm{~K}}$-peptide-PLGA

C
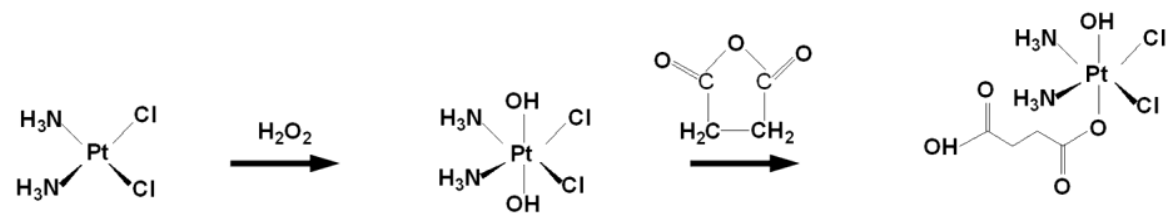

$\operatorname{Pt}(\mathbf{I V})$
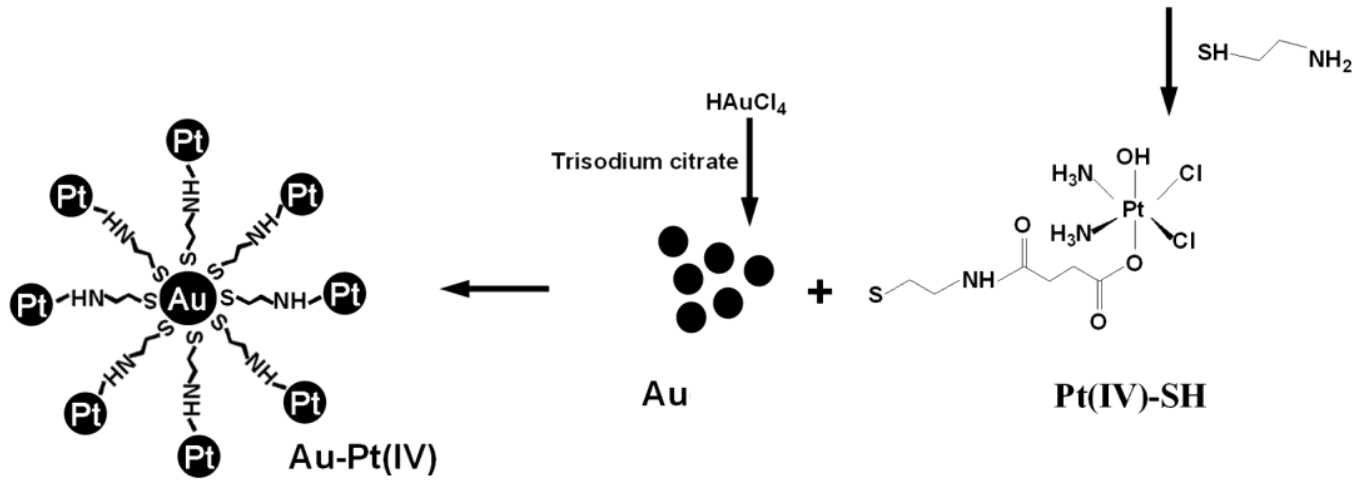

$\mathrm{Au}$

Pt(IV)-SH

Scheme S1. Synthesis of PLGA-PEG ${ }_{1 K}-\mathrm{CRGD}$ (a), PEG ${ }_{5 K}-$ peptide-PLGA (b), and Au-Pt (IV) (c). 

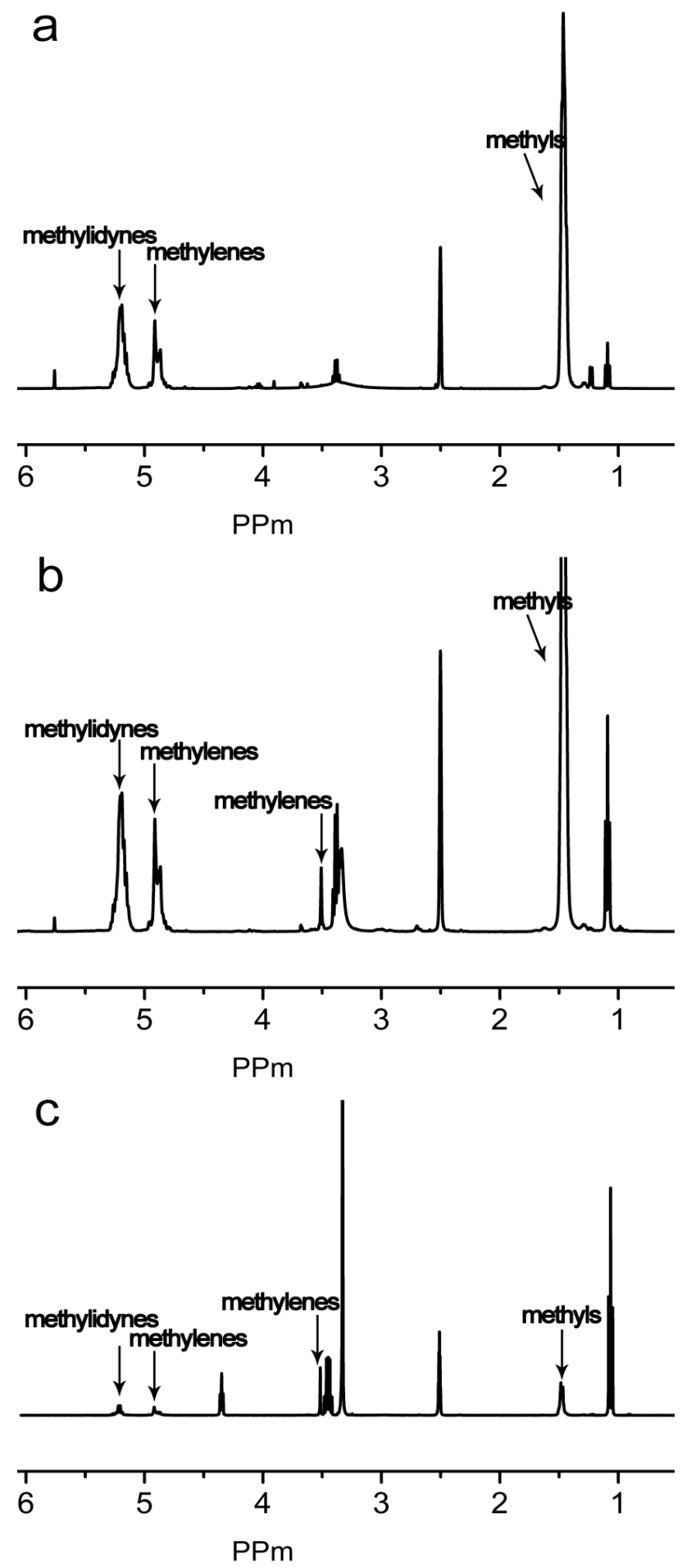

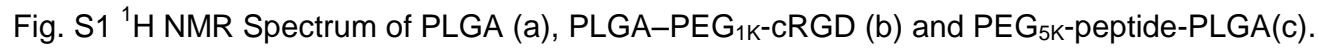


a

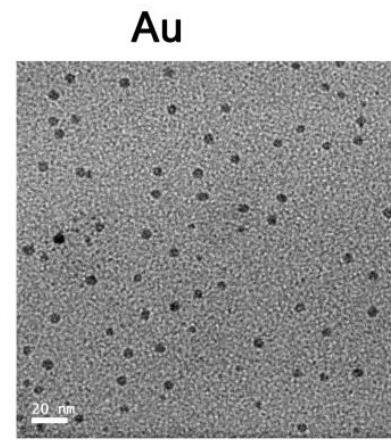

Au-Pt(IV)

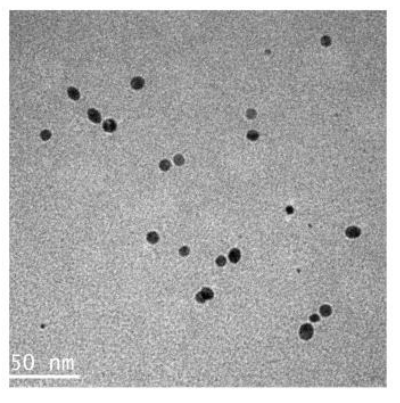

b

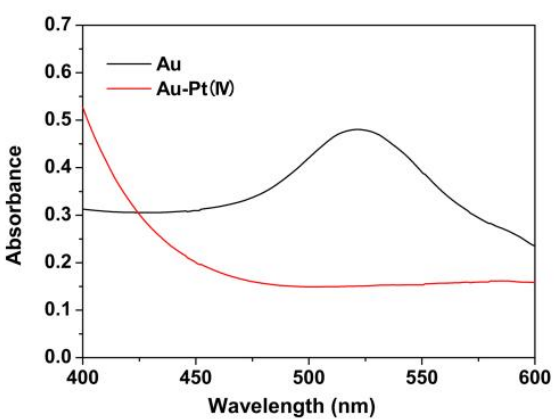

Fig. S2 Characterization of the $\mathrm{Au}-\mathrm{Pt}(\mathrm{IV})$ Nanoparticles. a. Au and $\mathrm{Au}-\mathrm{Pt}(\mathrm{IV})$ nanoparticles structure characterized by TEM. b. UV/vis spectrum of Au and Au-Pt(IV). The typical peak around $523 \mathrm{~nm}$ for $\mathrm{Au}$ nanoparticles disappeared in $\mathrm{Au}-\mathrm{Pt}(\mathrm{IV})$ nanoparticle.
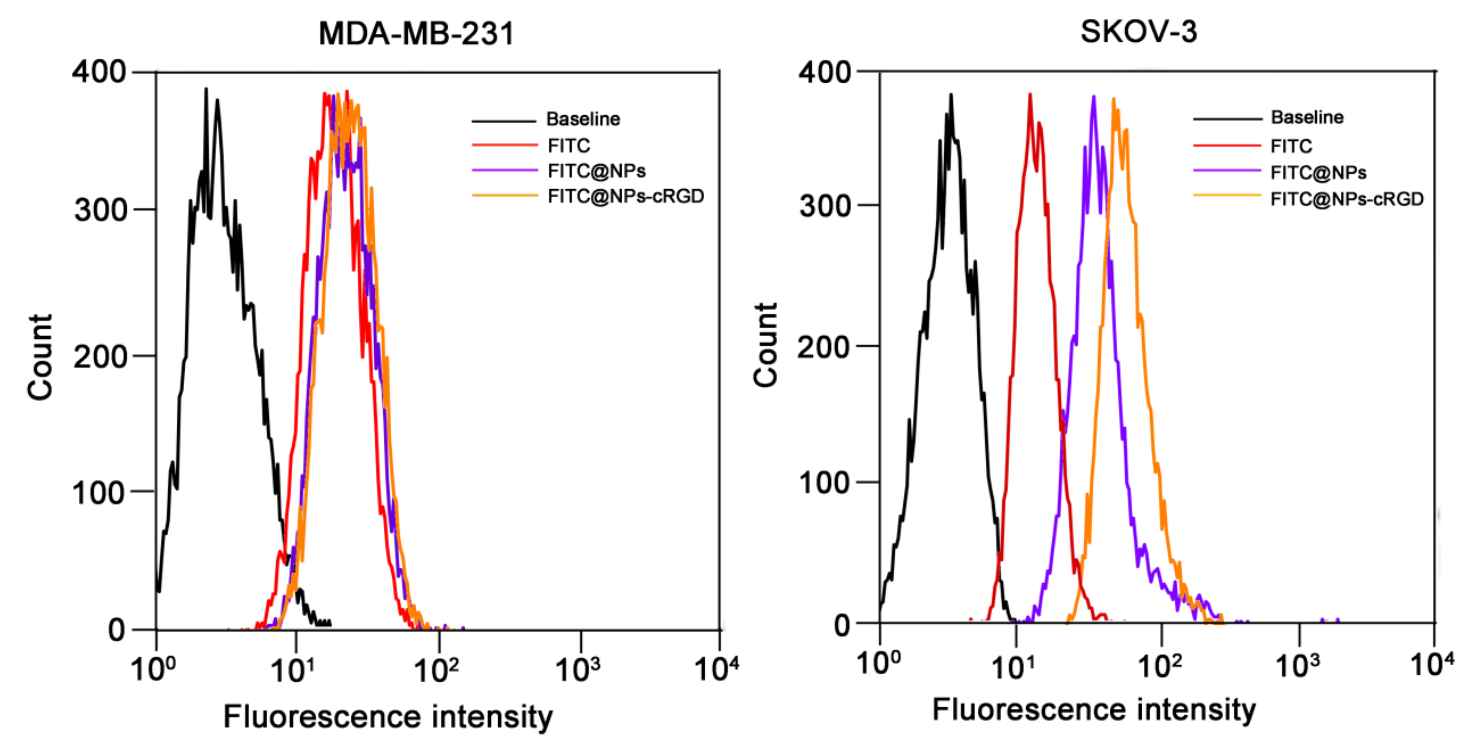

Fig. S3 Flow Cytometry Results of MDA-MB-231 and SKOV-3 cells after $4 \mathrm{~h}$ Incubation with FITC, FITC@NPs and FITC@NPs-cRGD 

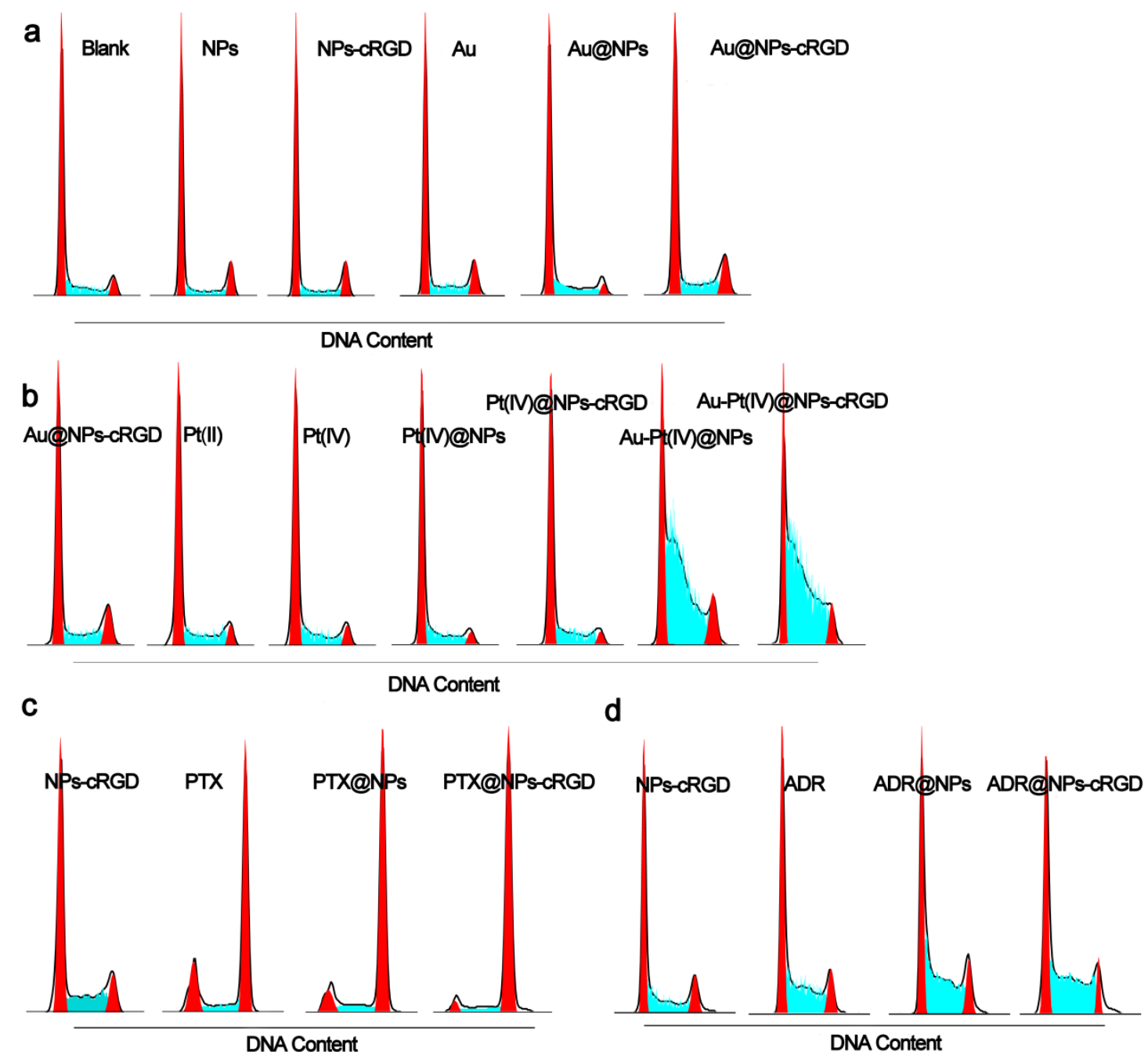

Fig. S4 Flow Cytometry Results of the Effect on the Cell Cycle of SKOV-3 in Nonsynchronized Cell Models. a, NPs-cRGD or Au@NPs-cRGD. b, Au-Pt(IV)@NPs-cRGD. c, PTX@NPs-cRGD. d, ADR@NPs-cRGD.
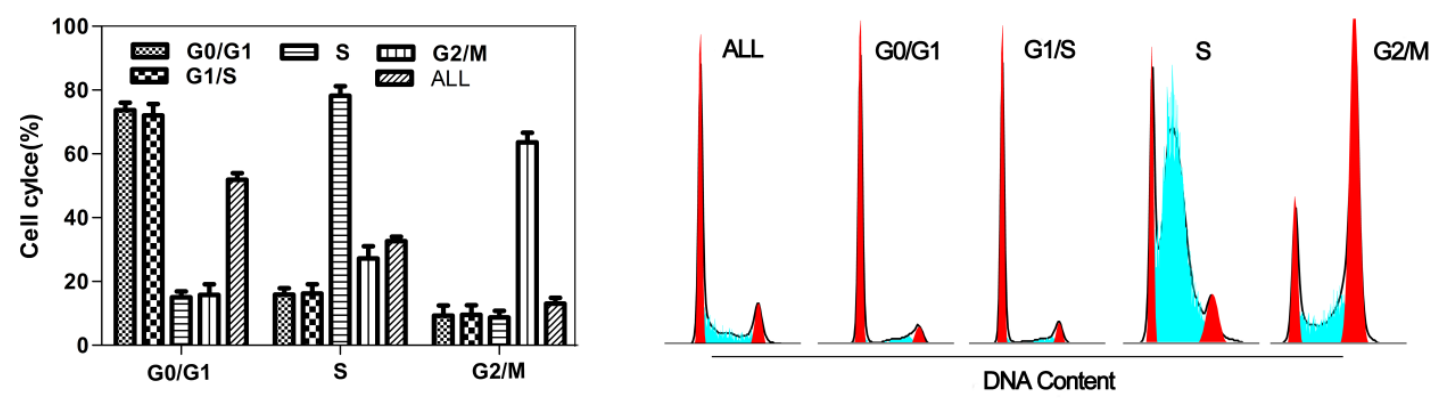

Fig. S5 Flow Cytometry Results of the Effect on Cell Cycle of SKOV-3 in Synchronized Cell Models. 

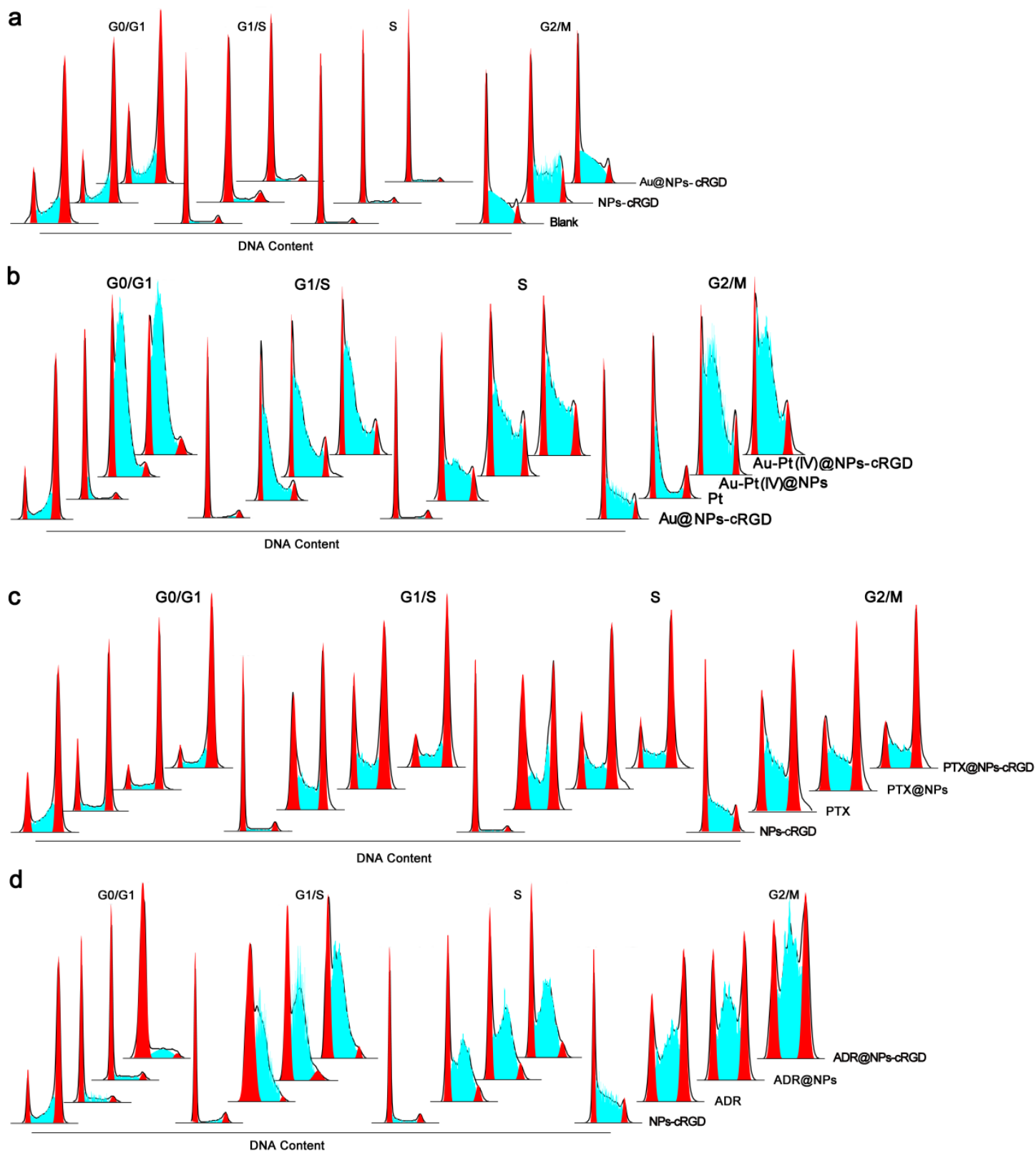

Fig. S6 Flow Cytometry Results of the Effect on Cell Cycle of SKOV-3 in Synchronized Cell Models. a, NPs-cRGD or Au@NPs-cRGD. b, Au-Pt(IV)@NPs-cRGD. c, PTX@NPs-cRGD. d, ADR@NPs-cRGD.

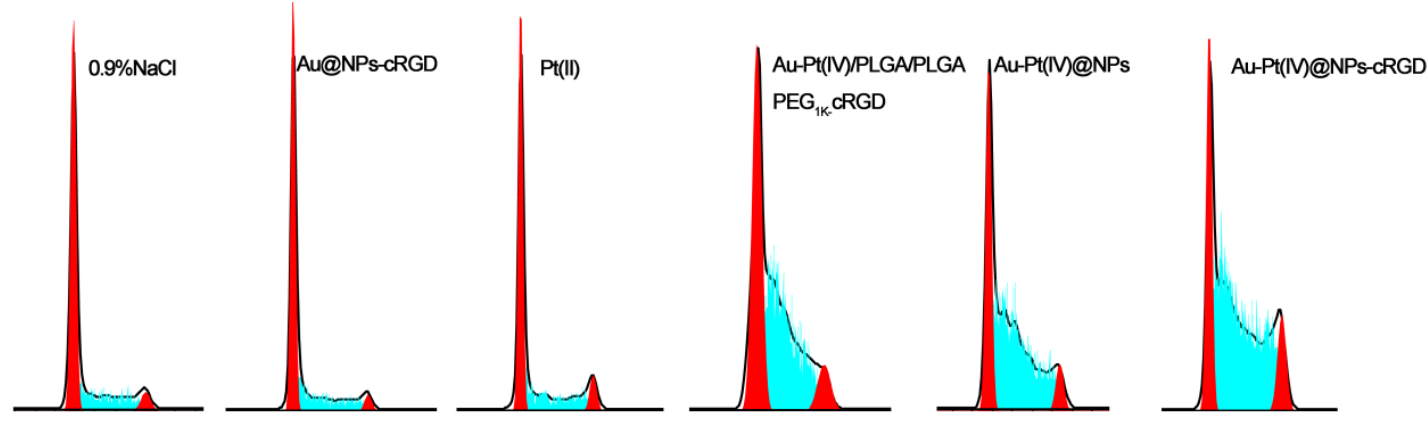

Fig. S7 Flow Cytometry Results of the Effect on Cell Cycle of SKOV-3 in Vivo. 


\section{Additional References}

(1) Kumar, A.; Huo, S.; Zhang, X.; Liu, J.; Tan, A.; Li, S.; Jin, S.; Xue, X.; Zhao, Y.; Ji, T.; Han, L.; Liu, H.; Zhang, X.; Zhang, J.; Zou, G.; Wang, T.; Tang, S.; Liang, X. J. Neuropilin-1-targeted Gold Nanoparticles Enhance Therapeutic Efficacy of Platinum (IV) Drug for Prostate Cancer Treatment. ACS nano 2014, 8, 4205-4220.

(2) Hori, H.; Teranishi, T.; Nakae, Y.; Seino, Y.; Miyake, M.; Yamada, S. Anomalous Magnetic Polarization Effect of Pd and Au Nano-particles. Phys. Lett. A 1999, 263, 406-410. 